\title{
Analysis of a new dimeric extradiol dioxygenase from a naphthalenesulfonate- degrading sphingomonad
}

\author{
Gesche Heiss, ${ }^{1}$ Claudia Müller, ${ }^{1}$ Josef Altenbuchner ${ }^{2}$ and Andreas Stolz ${ }^{1}$
}

Author for correspondence: Andreas Stolz. Tel: +49711 6855487. Fax: +49711 6855725.

e-mail: andreas.stolz@po.uni-stuttgart.de

Institut für Mikrobiologie ${ }^{1}$ and Institut für industrielle Genetik, ${ }^{2}$ Universität Stuttgart, 70569 Stuttgart, Germany

\begin{abstract}
A new extradiol dioxygenase was cloned by screening a gene bank from the naphthalenesulfonate-degrading bacterial strain BN6 for colonies with 2,3dihydroxybiphenyl dioxygenase (DHBPDO) activity. A $1.6 \mathrm{~kb}$ DNA fragment was sequenced and an ORF of 954 bp identified. Comparison of the deduced amino acid sequence of DHBPDO II from strain BN6 with previously published sequences showed the closest relationship to a metapyrocatechase (Mpcll) from Alcaligenes eutrophus JMP 222. Thus, the enzyme was only distantly related to the main groups of catechol 2,3-dioxygenases or DHBPDOs. The dioxygenase was expressed using a $\mathrm{T7}$ expression vector and the enzymic characteristics of the protein were examined. The enzyme oxidized 2,3dihydroxybiphenyl, 3-isopropylcatechol, 3-methylcatechol, 4-fluorocatechol and 1,2-dihydroxynaphthalene. Comparison of the UV/visible spectrum of the product formed from 3,5-dichlorocatechol with previous reports suggested that this substrate is oxidized by different extradiol dioxygenases either by proximal or distal ring cleavage. The enzyme required $\mathrm{Fe}^{2+}$ for maximal activity. In contrast to most other extradiol dioxygenases, the enzyme consisted of only two identical subunits.
\end{abstract}

Keywords: strain BN6, extradiol dioxygenases, 2,3-dihydroxybiphenyl dioxygenase, Sphingomonas

\section{INTRODUCTION}

The aerobic bacterial degradation of aromatic compounds usually proceeds via the formation of intermediates which carry two hydroxyl groups attached either in the ortho or para position to each other on the aromatic ring. If two vicinal hydroxyl groups are present, the ring fission occurs either between the two hydroxyl groups (intradiol cleavage) or at a bond proximal to one of the hydroxyl groups (extradiol cleavage). Extradiol dioxygenases play a key role in the degradation of various aromatic compounds such as toluene, naphthalene, biphenyl and polyaromatic hydrocarbons (Cerniglia, 1992; Dagley, 1975; Furukawa, 1994; Harayama et al., 1992; Harayama \& Timmis, 1992). Initially, it was assumed that the extradiol dioxygenases were a rather uniform evolutionarily

Abbreviations: 2,3-DHBP 2,3-dihydroxybiphenyl; DHBPDO, 2,3-dihydroxybiphenyl dioxygenase.

The GenBank accession number for the nucleotide sequence reported in this paper is U38978. related group of enzymes which all contain $\mathrm{Fe}^{2+}$ ions and belong to one superfamily (Harayama \& Rekik, 1989). Recently, evidence has accumulated from DNA sequencing experiments that certain extradiol dioxygenases, e.g. catechol 2,3-dioxygenase from Alcaligenes eutrophus JMP 222, protocatechuate 4,5-dioxygenase from Sphingomonas (Pseudomonas) paucimobilis or 3,4-dihydroxyphenylacetate 2,3-dioxygenase from Escherichia coli C, do not belong to the major superfamily of extradiol dioxygenases (Harayama et al., 1992; Kabisch \& Fortnagel, 1990a; Noda et al., 1990; Roper \& Cooper, 1990). Moreover, the genes for two 2,3-dihydroxybiphenyl 1,2-dioxygenases (DHBPDOs) have been cloned and sequenced ( $b p h C 2$ and $b p h C 3)$ from the biphenyl-degrading strain Rhodococcus globerulus $\mathrm{P} 6$, which according to their small subunit size, the composition of the holoenzymes and their amino acid sequences, constitute a separate group of extradiol dioxygenases (Asturias et al., 1994; Asturias \& Timmis, 1993). Furthermore, there have been reports on extradiol dioxygenases which are dependent on manganese or magnesium ions for their catalytic activity (Boldt $e$ t al., 
1995; Gibello et al., 1994; Que et al., 1981). Thus, it appears that the group of enzymes which catalyse the extradiol cleavage of aromatic compounds is more diverse than was previously believed.

We have recently reported the cloning and characterization of an extradiol dioxygenase from the bacterium strain BN6, which exhibited the highest degree of identity to DHBPDOs II and III from R. globerulus P6 and thus did not belong to the major group of extradiol dioxygenases (Heiss et al., 1995). Strain BN6 degrades amino- and hydroxynaphthalenesulfonates via substituted 1,2-dihydroxynaphthalenes to substituted salicylates (Kuhm et al., 1991, 1993; Nörtemann et al., 1986, 1994). Although clones derived from strain BN6 were obtained which were able to oxidize various catechol derivatives, the corresponding protein was not involved in the degradation of naphthalenesulfonates. In this study, another extradiol dioxygenase was obtained, from a gene bank of strain BN6, which was also significantly different from the members of the major superfamily of extradiol dioxygenases.

\section{METHODS}

Bacterial strains, culture conditions, plasmids and DNA manipulation techniques. The isolation and characterization of strain BN6 and the growth conditions have been described previously (Nörtemann et al., 1986). The strain has been deposited at DSM, Braunschweig, Germany, as Sphingomonas sp. BN6 DSM 6383. Escherichia coli strains were routinely cultured in Luria-Bertani medium. The $E$. coli strains used as host strains for recombinant DNA work, the techniques for DNA manipulations, the construction of the plasmid library and the detection of recombinants oxidizing 2,3-dihydroxybiphenyl (2,3-DHBP) have been described previously (Heiss et al., 1995).

Nucleotide sequence analysis. The DNA sequence was determined by the dideoxy chain-termination method with dsDNA of overlapping subclones in an automated DNA sequencing system (ALF Sequencer, Pharmacia) with fluorescently labelled primers (Heiss et al., 1995).

Sequence analysis and comparisons were done with the PC/GENE software package, version 6.7 (IntelliGenetics). The dendrogram based on the pairwise alignment of the extradiol dioxygenases was produced with the program CLUSTAL using the default parameters. Database searches were performed online using the programs BLASTN, BLASTP and TBLASTN (Altschul et al., 1990) on the BLAST electronic mail server from the National Center for Biotechnology Information, Bethesda, MD, USA.

Hyperexpression of DHBPDO. The strategy used for expression of $b p b C 2$ in $E$. coli BL21(DE3) under the control of the T7 promoter has been described previously (Heiss $e t$ al., 1995). The upstream primer (5' CGTCATATGAACCAGAACAGCCCGTCG $3^{\prime}$ ) incorporated a NdeI site (underlined) and the downstream primer ( $5^{\prime}$ CGCGGATCCTCAGGCCTCCGCCGGTTC $3^{\prime}$ ) incorporated a BamHI site (underlined). The amplified product was restricted with $\mathrm{NdeI}$ and Bam HI and ligated into pET11a to create pGHS201.

Relative activities of the enzyme preparation with (substituted) catechols. The preparation of cell extracts and the enzyme assay with 2,3-DHBP were performed as described previously (Heiss et al., 1995). For determination of the enzyme activities with catechol, 3-methyl-, 4-methyl-, 3isopropyl- and 4-chlorocatechol, and 2,3-DHBP the same reaction conditions and extinction coefficients as previously described were used (Heiss et al., 1995). The extinction coefficient for the oxidation product of 1,2-dihydroxynaphthalene was $\varepsilon_{331 \mathrm{~nm}}=2 \cdot 6 \mathrm{mM}^{-1} \mathrm{~cm}^{-1}$ (Kuhm et al., 1991). The extinction coefficients of the oxidation products of 3,5 dichlorocatechol, 3-bromo-5-chlorocatechol, 4-fluorocatechol and 3,4-DHBP were experimentally determined as $\varepsilon_{337 \mathrm{~nm}}=$ $10.0 \mathrm{mM}^{-1} \mathrm{~cm}^{-1}, \quad \varepsilon_{335 \mathrm{~nm}}=8.3 \mathrm{mM}^{-1} \mathrm{~cm}^{-1}, \quad \varepsilon_{382 \mathrm{~nm}}=$ $18.4 \mathrm{mM}^{-1} \mathrm{~cm}^{-1}$ and $\varepsilon_{383 \mathrm{~nm}}=12 \cdot 0 \mathrm{mM}^{-1} \mathrm{~cm}^{-1}$, respectively. The apparent enzyme activities were determined with freshly prepared solutions of these substrates.

Stability of the enzyme in cell-free extracts from $E$. coli BL21(DE3)(pGHS201). To determine the optimal conditions for storage and purification of the enzyme, crude extracts were incubated in different buffer systems alone, in the presence of protease inhibitors or compounds which are known to stabilize extradiol dioxygenases (Patel \& Barnsley, 1980; Scopes, 1982). After $4 \mathrm{~d}$ storage at $4{ }^{\circ} \mathrm{C}$ in sodium/potassium phosphate buffer or Tris/ $\mathrm{HCl}$ (each $100 \mathrm{mM}, \mathrm{pH} 7 \cdot 5$ ), 70 or $50 \%$ of the initial activity was recovered, respectively. The addition of PMSF $(1 \mathrm{mM})$, pepstatin A $(0 \cdot 1 \mu \mathrm{M})$, EDTA $(5 \mathrm{mM})$, glycerol $(30 \%, \mathrm{v} / \mathrm{v}), \beta$-mercaptoethanol $(9 \mathrm{mM})$, dithiothreitol ( $1 \mathrm{mM})$, glutathione $(4 \mathrm{mM})$, ethanol (10 or $20 \%, v / v)$ or acetone $(10 \%$ or $20 \%, v / v)$ did not stabilize the enzyme activity.

Enzyme purification and determination of molecular mass. The protein was purified at room temperature by use of a FPLC system, as previously described (Heiss et al., 1995).

Crude extract from E. coli BL21(DE3)(pGHS201) was applied to a Q-Sepharose fast-flow column (HR 16/10) and eluted at a flow rate of $4 \mathrm{ml} \mathrm{min}^{-1}$ with Tris $/ \mathrm{HCl}(50 \mathrm{mM}, \mathrm{pH} \mathrm{7.5})$ and a linear $\mathrm{NaCl}$ gradient $(0-2 \mathrm{M}$ over $300 \mathrm{ml})$. Fractions $(5 \mathrm{ml}$ each) were collected and those containing DHBPDO activity (eluting at an $\mathrm{NaCl}$ concentration of about $0 \cdot 28-0 \cdot 32 \mathrm{M}$ ) were pooled and transferred to a Phenyl-Superose fast flow column (HR 10/10). Protein was eluted with $150 \mathrm{ml}$ of a linear gradient of Tris/ $\mathrm{HCl}(50 \mathrm{mM}, \mathrm{pH} 7.5)$ containing $\left(\mathrm{NH}_{4}\right)_{2} \mathrm{SO}_{4}$ $(500 \mathrm{mM}$ in $50 \mathrm{mM}$ Tris $/ \mathrm{HCl}, \mathrm{pH} 7 \cdot 5)$. Both buffers contained

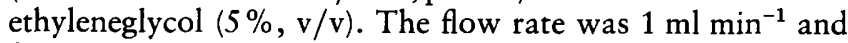
fractions of $4 \mathrm{ml}$ were sampled. The activity of DHBPDO was determined and those fractions with the highest activity [fractions 39-44, eluting at approximately $50 \mathrm{mM}\left(\mathrm{NH}_{4}\right)_{2} \mathrm{SO}_{4}$ ] were pooled and concentrated by ultrafiltration (Centricon10, Amicon). The sample was applied to a Hiload Superdex 200 (HR 16/60) column and eluted with $130 \mathrm{ml}$ Tris $/ \mathrm{HCl}$ buffer $(50 \mathrm{mM}, \mathrm{pH} 7.5)$ plus $\mathrm{NaCl}(100 \mathrm{mM})$ at a flow rate of $0.7 \mathrm{ml} \mathrm{min}{ }^{-1}$. Fractions $(2 \mathrm{ml} \mathrm{each})$ were collected and the active fractions combined.

SDSPAGE. SDS-PAGE was performed by the method of Laemmli (1970). Protein staining of the gels was performed with Coomassie brilliant blue G 250 (Merck).

Chemicals. The sources of 2,3-DHBP, 3,5- and 4,5-dichlorocatechol, 3-bromo-5-chlorocatechol, 3-isopropylcatechol and 3,4,6-trichlorocatechol were as described previously (Heiss et al., 1995). 3,4-DHBP was purchased from Promochem and 3chlorocatechol from Tokyo Kasei TCI. 3,6-Dichlorocatechol was obtained from Helix Biotech and 1,2,4-trihydroxybenzene from Aldrich. 4-Fluorocatechol was kindly provided by $M$. Schlömann (this laboratory). All other chemicals were obtained from Merck, Fluka, Sigma or Aldrich. 


\section{RESULTS}

Cloning and subcloning of the DNA fragment encoding the 2,3-DHBP oxidizing enzyme activity

The construction of the plasmid library and the spraytest for the identification of clones with the ability to oxidize 2,3-DHBP to the meta cleavage compound 2-hydroxy-6-oxo-6-phenylhexa-2,4-dienoate have been described previously (Heiss et al., 1995). In this gene bank, two types of recombinant plasmids encoding 2,3DHBP oxidizing activity were found. In a previous publication (Heiss et al., 1995), a clone containing a $9.75 \mathrm{~kb}$ insert was analysed (on pGHS1) which har- boured a gene encoding a DHBPDO (BphC). In this study, the second clone was examined. The gene for DHBPDO activity was originally located on a $4.75 \mathrm{~kb}$ $B g l I I$ fragment (pGHS2). In further subcloning experiments the gene (designated $b p h C 2$ ) was located on a $1.6 \mathrm{~kb}$ EcoRV fragment.

\section{Sequencing of the $1.6 \mathrm{~kb}$ fragment carrying the dioxygenase gene and sequence comparisons with other extradiol dioxygenases}

Various overlapping subclones were sequenced. The DNA and deduced amino acid sequences of the $1.6 \mathrm{~kb}$

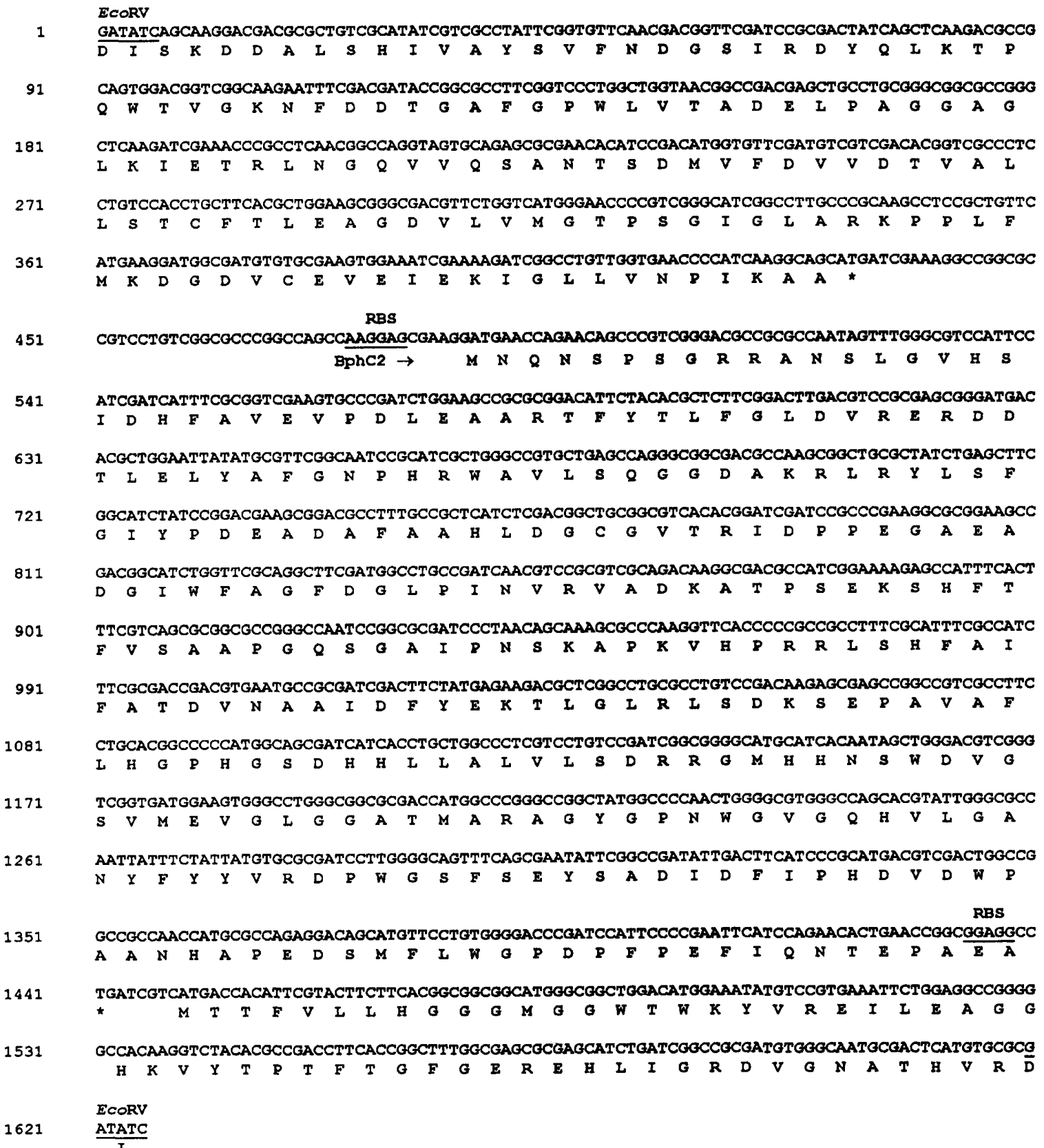

Fig. 1. Nucleotide sequence of the $1.6 \mathrm{~kb}$ EcoRV fragment containing bphC2. Ribosomal binding sites (RBS) and the ECORV restriction sites are underlined. Asterisks mark the ends of the ORFs. 


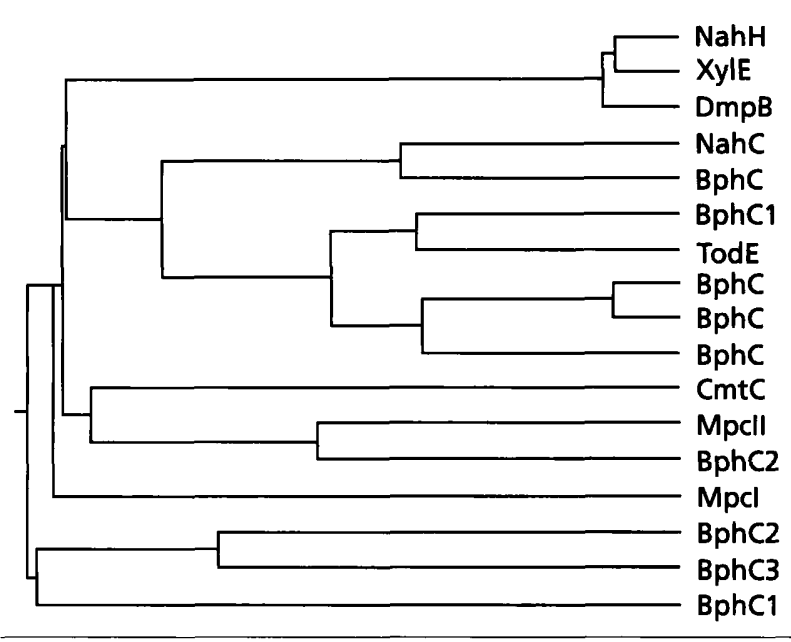

P. putida NAH7

P. putida TOL

P. putida pVI150

P. putida NAH7

S. paucimobilis Q1

R. globerulus P6

P. putida F1

Pseudomonas sp. LB400

P. putida KF715

Pseudomonas sp. KKS 102

P. putida F1

A. eutrophus JMP222

Strain BN6

A. eutrophus JMP222

R. globerulus P6

R. globerulus P6

Strain BN6
Fig. 2. Dendrogram resulting from pairwise alignments of amino acid sequences. $\mathrm{NahH}$, catechol 2,3-dioxygenase from $P$. putida NAH7 (Harayama et al., 1987); XylE, $P$. putida mt-2(TOL) (Nakai et al., 1983); DmpB, Pseudomonas sp. CF600(pVI150) (Shingler et al., 1992); TodE, P. putida F1 (Zylstra \& Gibson, 1989); Mpcl, A. eutrophus JMP222 (Kabisch \& Fortnagel, 1990a); Mpcll, A. eutrophus JMP222 (Kabisch \& Fortnagel, 1990b); NahC, 1,2-dihydroxynaphthalene dioxygenase from $P$. putida NAH7 (Harayama \& Rekik, 1989); CmtC, 2,3dihydroxy-p-cumate 3,4-dioxygenase from $P$. putida F1 (Eaton, 1996); BphC, BphC1, BphC2 and BphC3, DHBPDOs from $S$. paucimobilis Q1 (Taira et al., 1988), $R$. globerulus P6 (Asturias et al., 1994), Pseudomonas sp. LB 400 (Hofer et al., 1993), Pseudomonas sp. KKS102 (Kimbara et al., 1989), P. putida KF715 (Hayase et al., 1990) and strain BN6 (Heiss et al., 1995).
EcoRV fragment are shown in Fig. 1. A putative start codon (ATG) was found at positions $487-489$ of the nucleotide sequence. A putative ribosome binding site was found 6 bp upstream (AAGGAG). A termination codon (TGA) was identified at positions 1441-1443. This suggested an ORF of $954 \mathrm{bp}$, encoding a peptide with 318 aa and a molecular mass of $34802 \mathrm{Da}$. The protein sequence was pairwise aligned with the amino acid sequences of other extradiol dioxygenases. The resulting dendrogram is shown in Fig. 2. The enzyme from strain BN6 showed the highest degree of identity to a metapyrocatechase from A. eutrophus JMP 222 (MpcII). A recently described 2,3-dihydroxy- $p$-cumate 3,4-dioxygenase from Pseudomonas putida F1 (CmtC) (Eaton, 1996) appears to belong to the same group. The dendrogram suggested that the $b p h C 2$ gene did not belong to the major superfamily of extradiol dioxygenases as found previously for the $b p h C$ gene from the same strain. The pairwise alignment of the amino acid sequences of BphC2 and MpcII showed $46 \%$ identity (Fig. 3). Sequence analysis of the complete $1.6 \mathrm{~kb} E c o R V$ fragment revealed two further putative ORFs flanking $b p h C 2$, which were separated from $b p h C 2$ by short intervening sequences. One deduced ORF begins with an ATG 5 bp downstream of the $b p h C 2$ stop codon. The deduced amino acid sequence corresponded to 59 aa (Fig. 1) and showed $39-42 \%$ identity to sequences determined previously for 2-hydroxy-6-phenylhexa-2,4dienoate (HOPDA) hydrolases (BphD) from $P$. putida KF715, Pseudomonas sp. LB 400 and Comamonas testosteroni B-356 (Ahmad et al., 1995; Hayase et al., 1990; Hofer et al., 1993).

A second putative ORF was identified by translating the nucleotide sequence upstream of the $b p b C 2$ putative start site in all three reading frames, followed by a homology search with each deduced amino acid sequence. A sequence was identified which showed homology to the 2-hydroxyhepta-2,4-diene-1,7-dioate isomerase/5-oxopent-3-ene-1,2,5-tricarboxylate de-

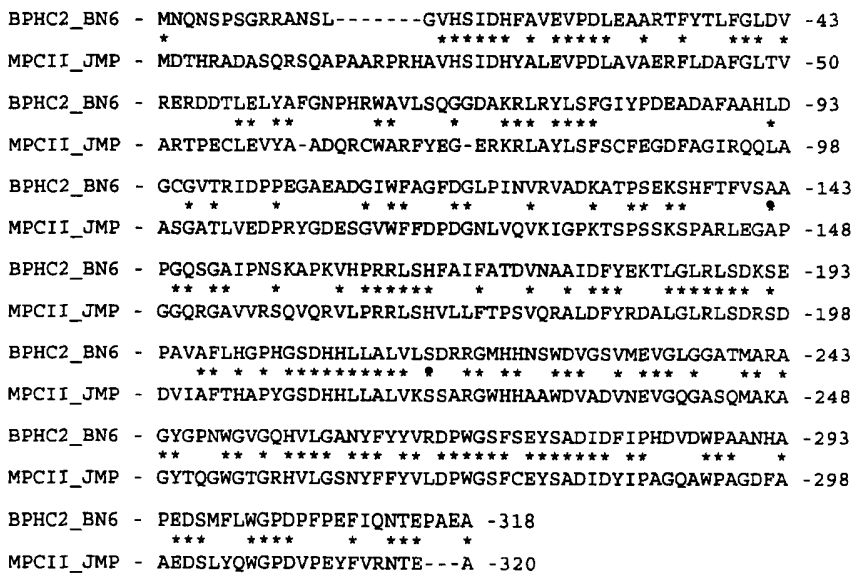

Fig. 3. Comparison of the amino acid sequences of $B p h C 2$ from strain BN6 and Mpcll from A. eutrophus JMP222 (Kabisch \& Fortnagel, 1990b). Identical amino acids are indicated by asterisks.

carboxylase from E. coli $\mathrm{C}$, which is part of the degradative pathway for homoprotocatechuate in this organism (Roper \& Cooper, 1990, 1993). From an overlap of 115 aa, 36 residues were identical.

\section{Analysis of the gene product}

To improve the expression of $b p h C 2$, the gene was cloned into the T7 expression vector pET11a. NdeI and Bam HI sites were introduced by PCR to enable ligation of the resulting fragment into pET11a, producing pGHS201, which was subsequently transformed into $E$. coli BL21(DE3). Expression of the NdeI-BamHI fragment in pGHS201 yielded an additional peptide in the crude extracts with an apparent molecular mass on an SDS-PAGE gel of $39( \pm 2) \mathrm{kDa}(n=3)$. 
Table 1. Purification of BphC2 from strain BN6

\begin{tabular}{|c|c|c|c|c|c|c|}
\hline Purification step & $\begin{array}{l}\text { Volume } \\
\text { (ml) }\end{array}$ & $\begin{array}{c}\text { Total } \\
\text { protein (mg) }\end{array}$ & $\begin{array}{c}\text { Total } \\
\text { activity }(\mathrm{U})\end{array}$ & $\begin{array}{l}\text { Specific activity } \\
\qquad\left(\mathrm{U} \mathrm{mg}^{-1}\right)\end{array}$ & $\begin{array}{c}\text { Recovery } \\
\text { factor }(\%)\end{array}$ & $\begin{array}{c}\text { Purification } \\
\text { (-fold) }\end{array}$ \\
\hline Crude extract & 10 & 413 & 438 & 1.06 & 100 & $1 \cdot 0$ \\
\hline Q-Sepharose & 30 & 97 & 424 & $4 \cdot 36$ & 97 & $4 \cdot 1$ \\
\hline Phenyl-Superose & 24 & 24 & 262 & $10 \cdot 9$ & 60 & $10 \cdot 3$ \\
\hline Gel filtration & 6 & 24 & 158 & 6.57 & 36 & $6 \cdot 2$ \\
\hline
\end{tabular}

Table 2. Relative activities for the oxidation of various aromatic diols by cell extracts of $E$. coli BL21(DE3)(pGHS201) encoding DHBPDO II (BphC2) from strain BN6 in comparison to those of $\mathrm{BphC}$ from the same strain

The specific activities with 2,3-DHBP $(=100 \% \text { ) were } 1 \cdot 7 \text { and } 2 \cdot 1 \mathrm{U} \text { (mg protein })^{-1}$ for BphC and BphC2, respectively. ND, Not determined.

\begin{tabular}{|c|c|c|c|c|}
\hline \multirow[t]{3}{*}{ Substrate (0.2 $\mathrm{mM}$ each) } & \multicolumn{4}{|c|}{ Enzyme } \\
\hline & \multicolumn{2}{|c|}{ BphC2 } & \multicolumn{2}{|l|}{ BphC } \\
\hline & $\begin{array}{c}\lambda_{\max } \text { of product } \\
(\mathbf{n m})\end{array}$ & $\begin{array}{l}\text { Relative } \\
\text { activity }\end{array}$ & $\begin{array}{c}\lambda_{\max } \text { of product } \\
(\mathbf{n m})\end{array}$ & $\begin{array}{l}\text { Relative } \\
\text { activity }\end{array}$ \\
\hline 2,3-DHBP & 434 & $100 \cdot 0$ & 434 & $100 \cdot 0$ \\
\hline 3,4-DHBP & 383 & 0.05 & 383 & 0.6 \\
\hline 1,2-Dihydroxynaphthalene & ND & $1 \cdot 8$ & ND & 0.0 \\
\hline Catechol & 375 & $0 \cdot 7$ & 375 & $0 \cdot 7$ \\
\hline 3-Methylcatechol & 385 & $6 \cdot 2$ & 384 & $10 \cdot 0$ \\
\hline 4-Methylcatechol & 382 & 0.03 & 382 & $0 \cdot 2$ \\
\hline 3-Isopropylcatechol & 388 & $86 \cdot 0$ & 384 & 12 \\
\hline 3-Chlorocatechol & ND & $0 \cdot 0$ & 378 & 16 \\
\hline 4-Chlorocatechol & 379 & $0 \cdot 3$ & 379 & $0 \cdot 9$ \\
\hline 3,4-Dichlorocatechol & ND & $0 \cdot 0$ & 380 & ND \\
\hline 3,5-Dichlorocatechol & 337 & $0 \cdot 6$ & 389 & $6 \cdot 0$ \\
\hline 3-Bromo-5-chlorocatechol & 335 & $0 \cdot 5$ & 384 & 13 \\
\hline 4-Fluorocatechol & 382 & $2 \cdot 6$ & ND & ND \\
\hline $\begin{array}{l}\text { 4-Hydroxycatechol }(=1,2,4- \\
\text { trihydroxybenzene) }\end{array}$ & 346 & ND & ND & $0 \cdot 0$ \\
\hline
\end{tabular}

Several attempts were made to purify the enzyme by FPLC under aerobic or anaerobic conditions in different buffer systems but did not yield homogeneous preparations of the enzyme. A typical purification scheme is shown in Table 1. The molecular mass of the enzyme was determined by gel filtration and estimated to be 65 $( \pm 5) \mathrm{kDa}(n=3)$. From this, it can be assumed that the enzyme consists of two subunits. In the chromatograms from the gel filtration step, only a single protein peak was observed which co-eluted with the enzyme activity. SDS-PAGE gels of samples from various purification steps characteristically showed an enrichment of a peptide with the expected mass of the DHBPDO subunit $(39 \mathrm{kDa})$. In addition, two further bands of different intensities corresponding to peptides with masses of approximately 14 and $30 \mathrm{kDa}$ were observed. These peptides could not be removed by further chromatography using different columns and their formation was observed in different buffer systems (Tris/ $\mathrm{HCl}$, sodium/ potassium phosphate or imidazole) in the presence of different protease inhibitors, enzyme stabilizing agents and also during FPLC under anaerobic conditions. The sequence data demonstrated that the two peptides ( 30 and $14 \mathrm{kDa}$ ) were direct products of the $39 \mathrm{kDa}$ peptide and were formed presumably prior to cell disruption (see Methods). Because of the unavailability of homogeneous preparations of DHBPDO, further experiments were performed with cell extracts from $E$. coli BL21(DE3)(pGHS201).

\section{Iron as cofactor}

The amino acid sequence of $\mathrm{BphC} 2$ suggested that the enzyme was not, or only marginally related to the major group of extradiol dioxygenases, which almost invariably contain $\mathrm{Fe}^{2+}$ ions as cofactor. Furthermore, 


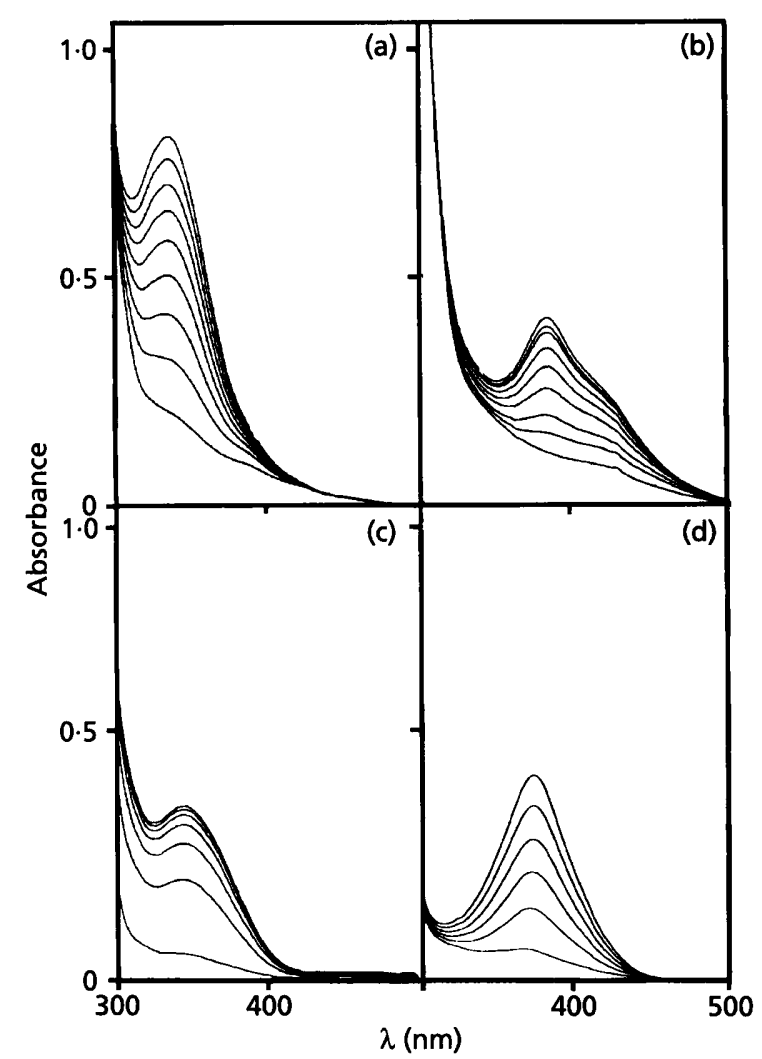

Fig. 4. Oxidation of (a) 1,2,4-trihydroxybenzene, (b) 3,4-DHBP, (c) 4-fluorocatechol and (d) 3,6-dichlorocatechol by BphC2 from strain BN6. The reaction mixtures contained 4-1400 $\mu \mathrm{g}$ cell extract and the respective substrate $(0.2 \mathrm{mM}$ each) in $1 \mathrm{ml}$ sodium/potassium phosphate buffer $(100 \mathrm{mM}, \mathrm{pH} 7.5)$. A spectrum was recorded every 1-5 min.

manganese- and magnesium-dependent extradiol dioxygenases have been described recently (Boldt et al., 1995; Gibello et al., 1994; Que et al., 1981). The cell extract

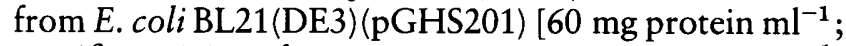
specific activity of $\mathrm{DHBPDO}=1.43 \mathrm{U}\left(\mathrm{mg}^{2} \text { protein }\right)^{-1}$ ] was incubated for 15 min with various $\mathrm{Fe}^{2+}$-chelating agents such as 8 -hydroxyquinoline, $o$-phenanthroline or $2,2^{\prime}$-dipyridyl ( $1 \mathrm{mM}$ each), or with the oxidizing agent $\mathrm{H}_{2} \mathrm{O}_{2}(0.1$ and $2 \%, v / v)$. The treatment with 8hydroxyquinoline, $o$-phenanthroline, $2,2^{\prime}$-dipyridyl or $\mathrm{H}_{2} \mathrm{O}_{2}(0 \cdot 1 \%)$ reduced the activity of DHBPDO to $67-86 \%$ of the control. With $2 \% \mathrm{H}_{2} \mathrm{O}_{2}$ a complete inhibition was observed ( $<2 \%$ of the original activity). This inactivated enzyme preparation was separated from residual $\mathrm{H}_{2} \mathrm{O}_{2}$ by ultrafiltration (Centricon-10, Amicon), rediluted to the original volume by the addition of $200 \mu \mathrm{l}$ buffer, divided into aliquots $(50 \mu \mathrm{l}$ each) and incubated with $\left(\mathrm{NH}_{4}\right)_{2} \mathrm{Fe}\left(\mathrm{SO}_{4}\right)_{2}(2 \mathrm{mM})$, $\left(\mathrm{NH}_{4}\right)_{2} \mathrm{Fe}\left(\mathrm{SO}_{4}\right)_{2}(2 \mathrm{mM})$ plus dithiothreitol $(5 \mathrm{mM})$, $\mathrm{MnCl}_{2}(2 \mathrm{mM}), \mathrm{MgCl}_{2}(2 \mathrm{mM})$ or without any supplements. After 10 min incubation at room temperature, 31 and $44 \%$ of the original enzyme activity was recovered in the samples which had been treated with $\left(\mathrm{NH}_{4}\right)_{2} \mathrm{Fe}$ $\left(\mathrm{SO}_{4}\right)_{2}$ or $\left(\mathrm{NH}_{4}\right)_{2} \mathrm{Fe}\left(\mathrm{SO}_{4}\right)_{2}$ plus dithiothreitol, respectively. In contrast, only 9,14 or $10 \%$ of the original
Table 3. Substrate specificity of BphC2 from strain BN6

The values were determined with cell-free extracts from $E$. coli BL21(DE3)(pGHS201) which expressed BphC2. The kinetic data were calculated using the computer program Enzfitter (Biosoft, Cambridge, UK, 1987), assuming Michaelis-Menten kinetics.

\begin{tabular}{|lcc|}
\hline Substrate & $\boldsymbol{V}_{\max }\left(\mathrm{U} \mathrm{mg}^{-1}\right)$ & $\boldsymbol{K}_{\mathrm{m}}(\mathrm{mM})$ \\
\hline 2,3-DHBP & $1 \cdot 5 \pm 0 \cdot 12$ & $0.003 \pm 0 \cdot 00092$ \\
Catechol & $0 \cdot 08 \pm 0 \cdot 0012$ & $0.8 \pm 0.029$ \\
3-Methylcatechol & $0 \cdot 27 \pm 0.0057$ & $0 \cdot 12 \pm 0.0097$ \\
3-Isopropylcatechol & $1 \cdot 37 \pm 0.028$ & $0.0056 \pm 0.00044$ \\
4-Fluorocatechol & $0 \cdot 10 \pm 0.0020$ & $0 \cdot 19 \pm 0.0092$ \\
\hline
\end{tabular}

activity was found in the samples which had been incubated with $\mathrm{MnCl}_{2}, \mathrm{MgCl}_{2}$ or with no additives, respectively.

\section{Oxidation of 2,3-DHBP, alkylcatechols and 1,2,4- trihydroxybenzene by cell-free extracts of $E$. coli BL21(DE3) carrying the recombinant plasmid}

Several different aromatic 1,2-diols were tested as substrates with crude extracts from $E$. coli BL21(DE3)(pGHS201) and the substrate specificity compared to that obtained previously for BphC from strain BN6. The products from 2,3-DHBP, catechol, and 3methyl- and 3-isopropylcatechol showed the same absorption spectra as the products formed by $\mathrm{BphC}$ (Table 2). As for BphC, the enzyme encoded by pGHS201 showed the highest specific activity with 2,3-DHBP and was therefore called $\mathrm{BphC}$. In comparison to $\mathrm{BphC}$, BphC2 showed a much higher relative activity with 3isopropylcatechol as substrate. In addition to the substrates oxidized by BphC, BphC2 also converted 1,2,4trihydroxybenzene (Table 2, Fig. 4).

The enzyme activity of $\mathrm{BphC} 2$ in the cell-free extracts was not inhibited by higher substrate concentrations. Therefore the $K_{\mathrm{m}}$ values and relative $V_{\max }$ values for different substrates were compared with the cell extracts using spectrophometric assays (Table 3 ).

The crude extracts did not oxidize protocatechuate, protocatechualdehyde, homoprotocatechuate, 3,4-dihydroxycinnamate, 3,4-dihydroxymandelate, 3,4-dihydroxyphenylglycol, 4-sulfocatechol or 4-nitrocatechol.

\section{Oxidation of halocatechols by $\mathrm{BphC}$ and $\mathrm{BphC2}$}

When BphC2 was incubated with 3-chlorocatechol, no reaction was observed spectrophotometrically. Furthermore, the enzyme was inactivated after incubation with 3-chlorocatechol as reported for extradiol dioxygenases from different bacteria (Adams et al., 1992; Arensdorf \& Focht, 1994; Bartels et al., 1984; Klecka \& Gibson, 1981; Wasserfallen et al., 1991).

With 3,5-dichlorocatechol as substrate, the formation of 
a new absorption maximum $\left(\lambda_{\max }\right)$ was observed. A surprising result was obtained when the absorption spectra of the products formed by $\mathrm{BphC}$ and $\mathrm{BphC} 2$ from 3,5-dichlorocatechol and 3-bromo-5-chlorocatechol were compared. The product formed by BphC2 from 3,5-dichlorocatechol had a $\lambda_{\max }$ at $337 \mathrm{~nm}$ and the product from 3-bromo-5-chlorocatechol at $335 \mathrm{~nm}$. These products were obviously different from the products obtained with $\mathrm{BphC}$, which showed $\lambda_{\max }$ at 388 and $384 \mathrm{~nm}$ for 3,5-dichlorocatechol and 3-bromo5 -chlorocatechol, respectively.

The reaction mixtures obtained from the oxidation of 3,5-dichlorocatechol by BphC or BphC2 were acidified to $\mathrm{pH} 2$ where both products lost their $\lambda_{\max }$ at $384 \mathrm{~nm}$ and $337 \mathrm{~nm}$, respectively. The solutions were immediately reneutralized and another set of spectra was recorded. Thus the $\lambda_{\max }$ at $337 \mathrm{~nm}$ did not reappear, while that of the product formed from BphC $\left(\lambda_{\max }=\right.$ $388 \mathrm{~nm}$ ) was at least partly restored. Both BphC and $\mathrm{BphC} 2$ oxidized 3,6-dichlorocatechol to a product which had a $\lambda_{\max }$ at $364 \mathrm{~nm}$ (Fig. 4). BphC and BphC2 did not oxidize 4,5-dichlorocatechol or 3,4,6-trichlorocatechol.

BphC2 oxidized 4-fluorocatechol to a product with a $\lambda_{\max }$ at $382 \mathrm{~nm}$ (Fig. 4, Table 2). This absorption maximum disappeared reversibly after acidification and irreversibly after incubation at $\mathrm{pH} 13$.

\section{DISCUSSION}

Analysis of gene banks from bacterial strains with the ability to degrade aromatic compounds for clones with DHBPDO activity often results in the isolation of different clones with DHBPDO activity of unknown physiological function. Using this method, three to four different DHBPDOs were found in R. globerulus P6 and $R$. erythropolis TA421 (Asturias \& Timmis, 1993; Maeda et al., 1995). Also, strain BN6 encodes at least three different extradiol dioxygenases, BphC, BphC2 and the 1,2-dihydroxynaphthalene dioxygenase which participates in the degradation of naphthalenesulfonates. According to the structure of the holoenzyme (dimer vs octamer), the amino-terminal amino acid sequence and the substrate specificity, $\mathrm{BphC} 2$ is clearly distinct from the 1,2-dihydroxynaphthalene dioxygenase from strain BN6 (Kuhm et al., 1991).

The deduced amino acid sequence of $\mathrm{BphC} 2$ from strain BN6 was significantly different to the corresponding sequences of the members of the main superfamily of extradiol dioxygenases which is represented by enzymes like catechol 2,3-dioxygenase from TOL or NAH7 plasmids, DHBPDO from Pseudomonas sp. LB400 or $P$. putida KF715, and 1,2-dihydroxynaphthalene dioxygenase from NAH7 (Harayama et al., 1992). The highest degree of amino acid identity was found between BphC2 and MpcII from A. eutrophus JMP 222. The dendrogram obtained by pairwise alignment of the amino acid sequences suggested that $\mathrm{BphC} 2$ clustered with MpcII and $\mathrm{CmtC}$ in a separate group (Fig. 2). Unfortunately, there is little published information about MpcII from A. eutrophus JMP 222 other than the nucleotide sequence and limited data about its oxidation of catechol, 3-methylcatechol and 4-methylcatechol (Kabisch \& Fortnagel, 1990b). Induction of a catechol 2,3dioxygenase has been found in A. eutrophus JMP 134 (= JMP 222 harbouring plasmid pJP4) after growth of the strain with 2-methylphenoxyacetate (Pieper et al., 1988). Consequently, MpcI or MpcII could be functional in the degradation of this substrate.

It has been suggested that the members of the major class of extradiol dioxygenases all contain an amino acid consensus sequence ([G,T,N,R]X[H,A]XXXXXXX$[\underline{L}, \mathrm{I}, \mathrm{V}, \mathrm{M}, \mathrm{F}] \mathrm{YXX}[\mathrm{D}, \mathrm{E}, \mathrm{T}, \mathrm{N}, \mathrm{A}] \mathrm{PX}[\mathrm{G}, \mathrm{P}] \mathrm{X}[2,3] \mathrm{E})$ (Boldt et al., 1995). A part of this consensus sequence has also been identified in BphC from strain BN6 (IYFYDPDGHMLE) (which is equivalent to the underlined part of the proposed consensus sequence shown above) (Heiss et al., 1995). The alignment of the deduced amino acid sequences from BphC2 from strain BN6 and MpcII from A. eutrophus JMP 222 demonstrated an almost perfect conservation of the sequence G[Q,R]HVLG[A,S]NYF[Y,F,]YV[R,L]DPWGSF[S,C]EYSADID (aa 252-279 in BphC2 and 257-284 in MpcII, Fig. 3) in both proteins, which is (at least for the sequence of BphC2) included in the proposed consensus sequence for extradiol dioxygenases (the corresponding amino acids are shown in bold letters above). This suggests that the catalytic centre of BphC2 resembles those of the major class of extradiol dioxygenases. This was also suggested by the observation that the enzyme was inactivated by $\mathrm{H}_{2} \mathrm{O}_{2}$ and could at least partially be reactivated by the addition of $\mathrm{Fe}^{2+}$ ions.

Comparison of the UV/visible spectra of the products formed from 3,5-dichlorocatechol by BphC and $\mathrm{BphC2}$ $\left(\lambda_{\max }\right.$ at 389 and $337 \mathrm{~nm}$, respectively) clearly demonstrated that two different products were formed. It seems reasonable to assume that one of the products results from a proximal mode of dioxygenolytic cleavage and the other product from a distal cleavage of the substrate. The product of the proximal cleavage would be the acyl chloride of a chlorohydroxy-substituted muconic acid. For the structurally related product $(=2$ hydroxymuconate) of the 1,2-dioxygenolytic cleavage of 1,2,3-trihydroxybenzene (pyrogallol), a $\lambda_{\max }$ at $290 \mathrm{~nm}$ has been described (Saeki et al., 1980). In contrast, the distal cleavage of 3,5-dichlorocatechol should give a dichlorinated muconic acid semialdehyde with the characteristic $\lambda_{\max }$ at $375-390 \mathrm{~nm}$. Thus 3,5-dichlorocatechol was probably oxidized by $\mathrm{BphC}$ by a distal cleavage mechanism, whereas $\mathrm{BphC2}$ oxidized this compound in a proximal manner. This is in good agreement with the fact that BphC oxidized 3-chlorocatechol to a product with $\lambda_{\max }$ at $378 \mathrm{~nm}$ which can only be explained by a distal cleavage of 3-chlorocatechol (Heiss et al., 1995). Presumably, BphC2 oxidized 3-chlorocatechol and 3,5-dichlorocatechol with low initial enzyme activities by proximal cleavage to the corresponding acyl chlorides which hydrolyse spontaneously to the muconic acids. Because the product from 3-chlorocatechol (2-hydroxymuconic acid) has a $\lambda_{\max }$ at $290 \mathrm{~nm}$ it cannot be detected spectrophoto- 
metrically in the presence of cell-free extract. In contrast, the reaction of 3,5-dichlorocatechol results in the formation of a $\lambda_{\max }$ at $337 \mathrm{~nm}$, which can be monitored sensitively using a spectrophotometer. Wasserfallen $e t$ al. (1991) showed that the catechol 2,3-dioxygenase from $P$. putida converted approximately 1000 molecules of 3-chlorocatechol before being inactivated. We are currently attempting to isolate the reaction products to definitively prove their structures.

\section{ACKNOWLEDGEMENTS}

The assistance of R. Getzlaff (GBF, Braunschweig) in performing the amino-terminal amino acid sequencing, $P$. Viell in the determination of the DNA sequence and A. E. Kuhm in the preparation of the figures are gratefully acknowledged. This work was supported by the Bundesministerium für Forschung und Technologie, Stuttgart, Germany, grant No. A02U-ZSP and by the Deutsche Forschungsgemeinschaft grant No. KN $183 / 5-1$.

\section{REFERENCES}

Adams, R. H., Huang, C.-M., Higson, F. K., Brenner, V. \& Focht, D. D. (1992). Construction of a 3-chlorobiphenyl-utilizing recombinant from an intergeneric mating. Appl Environ Microbiol 58, 647-652.

Ahmad, D., Fraser, J., Sylvestre, M., Larose, A., Khan, A., Bergeron, J., Juteau, J. M. \& Sondossi, M. (1995). Sequence of the $b p h D$ gene encoding 2-hydroxy-6-oxo-(phenyl/chlorophenyl)hexa-2,4-dienoic acid (HOP/cHOP) hydrolase involved in the biphenyl/polychlorinated biphenyl degradation pathway in Comamonas testosteroni: evidence suggesting involvement of $\mathrm{Ser}^{112}$ in catalytic activity. Gene 156, 69-74.

Altschul, S. F., Gish, W., Miller, W., Myers, E. W. \& Lipman, D. J. (1990). Basic local alignment search tool. J Mol Biol 215, 403-410.

Arensdorf, J. J. \& Focht, D. D. (1994). Formation of chlorocatechol meta cleavage products by a pseudomonad during metabolism of monochlorobiphenyls. Appl Environ Microbiol 60, 2884-2889.

Asturias, J. A. \& Timmis, K. N. (1993). Three different 2,3dihydroxybiphenyl 1,2-dioxygenase genes in the Gram-positive polychlorobiphenyl-degrading bacterium Rhodococcus globerulus P6. J Bacteriol 175, 4631-4640.

Asturias, J. A., Eltis, L. D., Prucha, M. \& Timmis, K. N. (1994). Analysis of three 2,3-dihydroxybiphenyl 1,2-dioxygenases found in R. globerulus P6. J Biol Chem 269, 7807-7815.

Bartels, I., Knackmuss, H.-J. \& Reineke, W. (1984). Suicide inactivation of catechol 2,3-dioxygenase from $P$. putida $\mathrm{mt}-2$ by 3-halocatechols. Appl Environ Microbiol 47, 500-505.

Boldt, Y. R., Sadowsky, M. J., Elis, L. B. M., Que, L., Jr \& Wackett, L. P. (1995). A manganese-dependent dioxygenase from Arthrobacter globiformis CM-2 belongs to the major extradiol dioxygenase family. J Bacteriol 177, 1225-1232.

Cerniglia, C. E. (1992). Biodegradation of polycyclic aromatic hydrocarbons. Biodegradation 3, 351-368.

Dagley, S. (1975). A biochemical approach to some problems of environmental pollution. Essays Biochem 11, 81-138.

Eaton, R. W. (1996). p-Cumate catabolic pathway in Pseudomonas putida F1: cloning and characterization of DNA carrying the $c m t$ operon. J Bacteriol 178, 1351-1362.
Furukawa, K. (1994). Molecular genetics and evolutionary relationship of PCB-degrading bacteria. Biodegradation 5, 289-300. Gibello, A., Ferrer, E., Martin, M. \& Garrido-Pertierra, A. (1994). 3,4-Dihydroxyphenylacetate 2,3-dioxygenase from Klebsiella pneumoniae, a $\mathrm{Mg}^{2+}$-containing dioxygenase involved in aromatic catabolism. Biochem J 301, 145-150.

Harayama, S. \& Rekik, M. (1989). Bacterial aromatic ring-cleavage enzymes are classified into two different gene families. $J$ Biol Chem 264, 15328-15333.

Harayama, S. \& Timmis, K. (1992). Aerobic biodegradation of aromatic hydrocarbons by bacteria. In Metal lons in Biological Systems, vol. 28, pp. 99-156. Edited by H. Sigel \& A. Sigel. New York: Marcel Dekker Inc.

Harayama, S., Rekik, M., Wasserfallen, A. \& Bairoch, A. (1987). Evolutionary relationships between catabolic pathways for a romatics: conservation of gene order and nucleotide sequences of catechol oxidation genes of pWW0 and NAH7 plasmids. $\mathrm{Mol}$ Gen Genet 210, 241-247.

Harayama, S., Kok, M. \& Neidle, E. L. (1992). Functional and evolutionary relationships among diverse oxygenases. Annu Rev Microbiol 46, 565-601.

Hayase, N., Taira, K. \& Furukawa, K. (1990). Pseudomonas putida KF715 $b p h A B C D$ operon encoding biphenyl and polychlorinated biphenyl degradation: cloning, analysis and expression in soil bacteria. J Bacteriol 172, 1160-1164.

Heiss, G., Stolz, A., Kuhm, A. E., Muller, C., Klein, J., Altenbuchner, J. \& Knackmuss, H.-J. (1995). Characterization of a 2,3-dihydroxybiphenyl dioxygenase from the naphthalenesulfonate-degrading bacterium strain BN6. J Bacteriol 177, 5865-5871.

Hofer, B., Eltis, L. D., Dowling, D. N. \& Timmis, K. N. (1993). Genetic analysis of a Pseudomonas locus encoding a pathway for biphenyl/polychlorinated biphenyl degradation. Gene 130, 4755 .

Kabisch, M. \& Fortnagel, P. (1990a). Nucleotide sequence of metapyrocatechase I (catechol 2,3-oxygenase I) gene mpcl from Alcaligenes eutrophus JMP 222. Nucleic Acids Res 18, 3405-3406.

Kabisch, M. \& Fortnagel, P. (1990b). Nucleotide sequence of metapyrocatechase II (catechol 2,3-oxygenase II) gene mpcII from Alcaligenes eutrophus JMP 222. Nucleic Acids Res 18, 5543.

Kimbara, K., Hashimoto, T., Fukuda, M., Koana, T., Tagaki, M., Oishi, M. \& Yano, K. (1989). Cloning and sequencing of two tandem genes involved in degradation of 2,3-dihydroxybiphenyl to benzoic acid in the polychlorinated biphenyl-degrading soil bacterium Pseudomonas sp. strain KKS102. J Bacteriol 171, 2740-2747.

Kležka, G. M. \& Gibson, D. T. (1981). Inhibition of catechol 2,3dioxygenase from Pseudomonas putida mt-2 by 3-chlorocatechol. Appl Environ Microbiol 41, 1159-1165.

Kuhm, A. E., Stolz, A., Ngai, K.-L. \& Knackmuss, H.-J. (1991). Purification and characterization of a 1,2-dihydroxynaphthalene dioxygenase from a bacterium that degrades naphthalenesulfonic acids. J Bacteriol 173, 3795-3802.

Kuhm, A. E., Knackmuss, H.-J. \& Stolz, A. (1993). Purification and properties of $2^{\prime}$-hydroxybenzalpyruvate aldolase from a bacterium that degrades naphthalenesulfonates. $J$ Biol Chem 268, 9484-9489.

Laemmli, U. K. (1970). Cleavage of structural proteins during the assembly of the head of bacteriophage T4. Nature 227, 680-685.

Maeda, M., Chung, S.-Y., Song, E. \& Kudo, T. (1995). Multiple genes encoding 2,3-dihydroxybiphenyl 1,2-dioxygenase in the 
Gram-positive polychlorinated biphenyl-degrading bacterium Rhodococcus erythropolis TA421, isolated from a termite ecosystem. Appl Environ Microbiol 61, 549-555.

Nakai, C., Kagamiyama, H., Nozaki, M., Nagasawa, T., Inouye, S., Ebina, Y. \& Nakazawa, A. (1983). Complete nucleotide sequence of the metapyrocatechase gene on the TOL plasmid of Pseudomonas putida mt-2. J Biol Chem 258, 2923-2928.

Noda, Y., Nishikawa, S., Shiozuka, K.-I., Kadokura, H., Kakajima, H., Yoda, K., Katayama, Y., Morohoshi, N., Haraguchi, T. \& Yamasaki, M. (1990). Molecular cloning of the protocatechuate 4,5-dioxygenase genes of Pseudomonas paucimobilis. J Bacteriol 172, 2704-2709.

Norrtemann, B., Baumgarten, J., Rast, H. G. \& Knackmuss, H.-J. (1986). Bacterial communities degrading amino- and hydroxynaphthalene-2-sulfonates. Appl Environ Microbiol 52, $1195-$ 1201.

Nörtemann, B., Kuhm, A. E., Knackmuss, H.-J. \& Stolz, A. (1994). Conversion of substituted naphthalenesulfonates by Pseudomonas sp. BN6. Arch Microbiol 161, 320-327.

Patel, T. R. \& Barnsley, E. A. (1980). Naphthalene metabolism by pseudomonads: purification and properties of 1,2-dihydroxynaphthalene oxygenase. J Bacteriol 143, 668-673.

Pieper, D. H., Reineke, W., Engesser, K.-H. \& Knackmuss, H.-J. (1988). Metabolism of 2,4-dichlorophenoxyacetic acid, 4-chloro2-methylphenoxyacetic acid and 2-methylphenoxyacetic acid by Alcaligenes eutrophus JMP 134. Arch Microbiol 150, 95-102.

Que, L., Jr, Widom, J. \& Crawford, R. L. (1981). 3,4-Dihydroxyphenylacetate 2,3-dioxygenase. A manganese(II) dioxygenase from Bacillus brevis. J Biol Chem 256, 10941-10944.

Roper, D. I. \& Cooper, R. A. (1990). Subcloning and nucleotide sequence of the 3,4-dihydroxyphenylacetate (homoprotocatechuate) 2,3-dioxygenase gene from Escherichia coli C. FEBS Lett 275, 53-57.

Roper, D. I. \& Cooper, R. A. (1993). Purification, nucleotide sequence and some properties of a bifunctional isomerase/ decarboxylase from the homoprotocatechuate degradative pathway of Escherichia coli C. Eur J Biochem 217, 575-580.

Saeki, Y., Nozaki, M. \& Senoh, S. (1980). Cleavage of pyrogallol by non-heme iron containing dioxygenases. J Biol Chem 255, $8465-8471$.

Scopes, R. K. (1982). Protein Purification. New York: SpringerVerlag.

Shingler, V., Powlowski, J. \& Marklund, U. (1992). Nucleotide sequence and functional analysis of the complete phenol/3,4dimethylphenol catabolic pathway of Pseudomonas sp. strain CF600. J Bacteriol 174, 711-724.

Taira, K., Hayase, N., Arimura, N., Yamashita, S., Miyazaki, T. \& Furukawa, K. (1988). Cloning and nucleotide sequence of the 2,3dihydroxybiphenyl dioxygenase from the PCB-degrading strain of Pseudomonas paucimobilis Q1. Biochemistry 27, 3990-3996.

Wasserfallen, A., Rekik, M. \& Harayama, D. (1991). A Pseudomonas putida strain able to degrade $m$-toluate in the presence of 3-chlorocatechol. Bio/Technology 9, 296-298.

Zylstra, G. J. \& Gibson, D. T. (1989). Toluene degradation by Pseudomonas putida F1. Nucleotide sequence of the todC1C2$B A D E$ genes and their expression in Escherichia coli. J Biol Chem 264, 14940-14946.

Received 9 October 1996; revised 19 December 1996; accepted 31 December 1996. 